\title{
Antihypertensive drug telmisartan suppresses the proliferation of gastric cancer cells in vitro and in vivo
}

\author{
NAOKI FUJTAA $^{1}$, KOJI FUJITA ${ }^{1}$, HISAKAZU IWAMA ${ }^{2}$, HIDEKI KOBARA ${ }^{1}$, \\ SHINTARO FUJIHARA ${ }^{1}$, TAIGA CHIYO ${ }^{1}$, DAISUKE NAMIMA ${ }^{1}$, HIROKI YAMANA ${ }^{1}$, \\ TOSHIAKI KONO ${ }^{1}$, KEI TAKUMA ${ }^{1}$, MASAHIRO HIRATA ${ }^{1}$, KIYOYUKI KOBAYASHI ${ }^{1}$, \\ KIYOHITO KATO $^{1}$, HIDEKI KAMADA ${ }^{1}$, ASAHIRO MORISHITA ${ }^{1}$, KUNIHIKO TSUTSUI ${ }^{1}$, \\ TAKASHI HIMOTO $^{1}$, KEIICHI OKANO ${ }^{3}$, YASUYUKI SUZUKI ${ }^{3}$ and TSUTOMU MASAKI $^{1}$ \\ ${ }^{1}$ Department of Gastroenterology and Neurology; ${ }^{2}$ Life Science Research Center; \\ ${ }^{3}$ Department of Gastroenterological Surgery, Kagawa University, Takamatsu, Kagawa 761-0793, Japan
}

Received November 8, 2019; Accepted April 13, 2020

DOI: $10.3892 / o r .2020 .7607$

\begin{abstract}
Gastric cancer is one of the most common malignancies diagnosed worldwide. Telmisartan, an angiotensin receptor blocker (ARB), suppresses the proliferation of cancer cells and the growth of tumors through an unknown mechanism. To identify the mechanism, the present study was designed to evaluate the effects of telmisartan on gastric cancer cell lines and tumors in vitro and in vivo and the associated signaling molecules were identified. It was shown here that telmisartan suppressed the proliferation of the cultured human gastric cancer cell lines MKN74, MKN1 and MKN45 as detected in the CCK- 8 assay. In a mouse xenograft model of gastric cancer, telmisartan suppressed tumor growth by arresting the cell cycle at the G0/G1 phase through inhibition of the expression of cyclin D1, the catalytic subunit of cyclin dependent kinase 4 (CDK4), as well as the phosphorylation of the tumor suppressor retinoblastoma $(\mathrm{pRb})$ protein as detected by western blotting. Notably, telmisartan did not induce apoptosis, as indicated by consistent levels of caspase-cleaved keratin 18 in MKN74 cells. Furthermore, telmisartan inhibited the phosphorylation of epidermal growth factor receptor (EGFR) and increased the levels of the angiogenesis-related protein tissue inhibitor of metalloproteinase-1 (TIMP-1). Analyses of microarrays revealed that telmisartan altered the expression of miRNAs in MKN74 cells. In conclusion, telmisartan suppressed the proliferation of human gastric cancer cells by inducing cell cycle arrest.
\end{abstract}

Correspondence to: Professor Tsutomu Masaki, Department of Gastroenterology and Neurology, Kagawa University, 1750-1 Ikenobe, Miki-cho, Kita-gun, Takamatsu, Kagawa 761-0793, Japan

E-mail: tmasaki@med.kagawa-u.ac.jp

Key words: gastric cancer, telmisartan, cyclin, microRNA, angiotensin II type 1 receptor blocker, cell cycle arrest, receptor tyrosine kinase, angiogenesis

\section{Introduction}

Gastric cancer is one of the most commonly diagnosed malignant tumors (1). The incidence of gastric cancer is highest in East Asia, followed by Eastern Europe, South America, and the northeastern region of Japan (1). Despite the decline in incidence after the discovery of Helicobacter pylori, the absolute number of annual cases continues to increase worldwide (2), which is attributed to an aging population (2). Furthermore, the trend toward declining incidence was recently interrupted and replaced by an upward trend in younger patients for unknown reasons (2). Although the incidence of distal gastric cancer has significantly declined, the incidence of adenocarcinoma at the esophagogastric junction and proximal stomach has exceeded the incidences of other cancers (3). Aside from surgery, therapy for gastric cancer has evolved from chemotherapy to targeted therapy and immunotherapy, which improve prognosis to some extent, although the survival of patients with late-stage gastric cancer remains poor (4). Therefore, investigators must consider different approaches for treating gastric cancer.

Genetic abnormalities occur in gastric cancer that are associated with altered expression of the cell-cycle regulator cyclin and cyclin-dependent kinases (CDKs) $(5,6)$. Overexpression of cyclin $\mathrm{E}$ is a particularly frequent event in gastric carcinomas $(5,6)$ and may therefore serve as an indicator of the malignant transformation of dysplastic cells (7) and tumor aggressiveness, once an invasive cancer develops $(6,8)$. Moreover, overexpression of cyclin D1, cyclin D2, and the catalytic subunit of CDK4 are associated with tumor progression (9).

Angiotensin II receptor type 1 (AT1) receptor blockers (ARBs) are used to treat hypertension, chronic heart failure, and chronic kidney disease. Evidence indicates that angiotensin II affects cancer growth and that ARBs antagonize AT1 receptors to suppress tumor growth. (10-12). Telmisartan is an antihypertensive drug that induces apoptosis of urological and gynecologic cancer cell lines $(13,14)$. In contrast, telmisartan induces G1 arrest in cancer cell lines such as those derived from adult $\mathrm{T}$ cell leukemias (15), esophageal adenocarcinomas $(16)$, and hepatobiliary malignancies $(17,18)$. Moreover, ARBs inhibit cell proliferation and angiogenesis (19). However, 
we lack sufficient knowledge of the direct mechanism through which telmisartan suppresses the growth of gastric cancer cells.

Here we report the antitumor effects of telmisartan on human gastric cancer cell lines and in a mouse xenograft model of gastric cancer. We show that telmisartan induced cell cycle arrest in gastric cancer cell lines but did not induce apoptosis. Telmisartan caused G0/G1-phase arrest by decreasing the levels of cyclin D1 and CDK complexes. We investigated the effect of telmisartan on gastric cancer cell growth in a xenograft model. Moreover, we analyzed the association of receptor tyrosine kinases (RTKs), angiogenesis, and microRNAs with tumor suppression.

\section{Materials and methods}

Cell culture. The human gastric cancer cell lines MKN74, MKN1 and MKN45, which were obtained from the Japanese Cancer Research Resources Bank (Osaka, Japan), were maintained at $37^{\circ} \mathrm{C}$ in an atmosphere containing $5 \% \mathrm{CO}_{2}$ in Dulbecco's modified Eagle's medium (Gibco Invitrogen; Thermo Fisher Scientific, Inc.) supplemented with $10 \%$ fetal bovine serum (FBS), $20 \mathrm{U} / \mathrm{ml}$ penicillin, and $100 \mu \mathrm{g} / \mathrm{ml}$ streptomycin.

Cell proliferation assay. The cell proliferation assay was performed according to a previously published procedure (16).

Cell cycle and apoptosis analyses. Cell cycle and apoptosis analyses were performed according to previously published procedures (16). Detailed information about these analyses is provided in Data S1.

Gel electrophoresis and western blotting. Gel electrophoresis and western blotting were performed according to previously published procedures (16). Briefly, cells were treated with telmisartan or DMSO and lysed in the presence of a protease inhibitor cocktail. A NanoDrop 2000 fluorescence spectrometer (Thermo Fisher Scientific, Inc.) was used for measuring of protein concentrations. Aliquots (1-10 $\mu \mathrm{g})$ were added to sample buffer and heated at $100^{\circ} \mathrm{C}$ for $5 \mathrm{~min}$. Proteins were separated using $10 \%$ sodium dodecyl sulfate polyacrylamide gel electrophoresis and electrophoretically transferred to a nitrocellulose membrane (GE Healthcare). After blocking in 5\% skim milk in $0.05 \%$ Tween-20/TBS buffer, the membranes were incubated with primary antibodies and then with peroxidase-conjugated secondary antibodies in 5\% skim milk in $0.05 \%$ Tween-20/TBS buffer. Immunoreactive proteins were visualized using an ImageQuant LAS4010 (GE Healthcare, Tokyo, Japan). Band intensities were semi-quantified using ImageJ software v1.52q (National Institutes of Health) and normalized to $\beta$-actin. Information concerning the antibodies is provided in Data S1.

Apoptosis assay. Caspase-cleaved cytokeratin 18 (cCK18) expression was evaluated using an M30 Apoptosense ELISA kit (Funakoshi Co.). The ELISA assay was performed according to a previously published procedure (18). Details of the assay are provided in Data S1.

Antibody array analyses of phosphorylated receptor tyrosine kinases ( $p$-RTKs) and angiogenesis-related protein profiles.
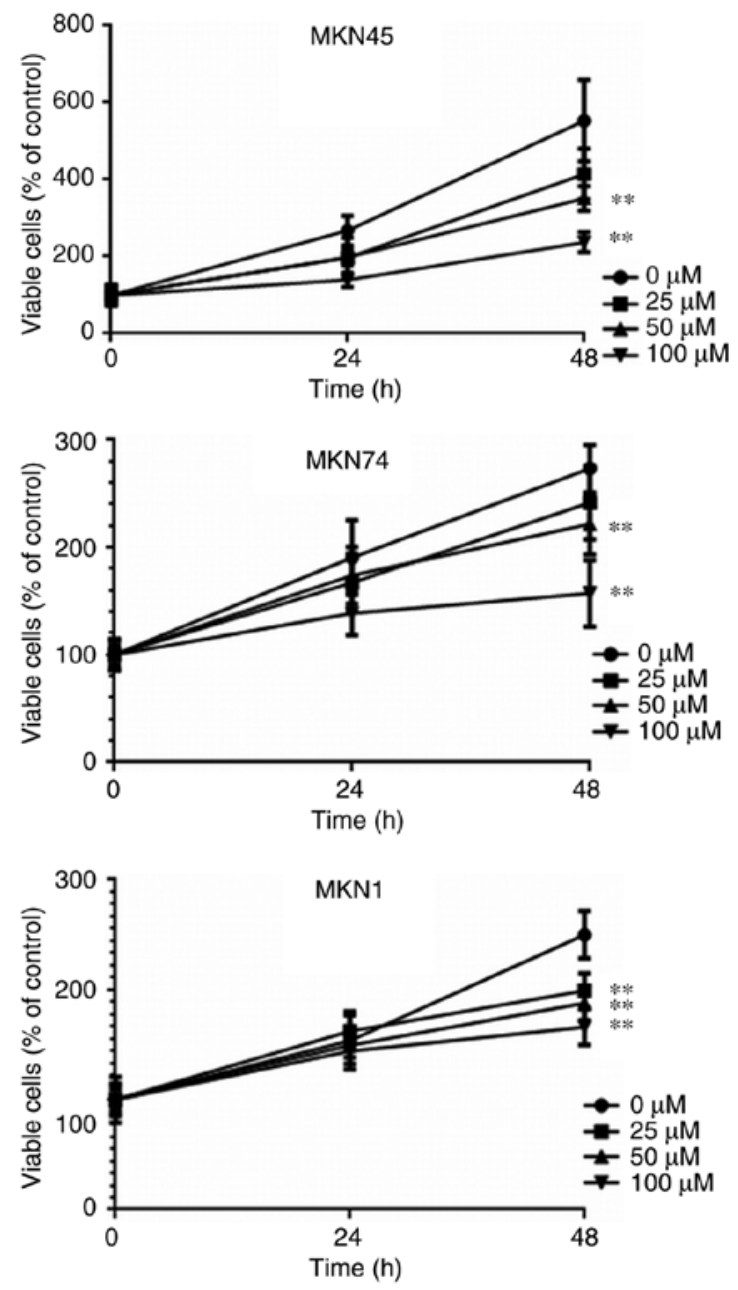

Figure 1. Telmisartan suppresses the proliferation of gastric cancer cells. MKN74, MKN1, and MKN45 cells were treated with $0,25,50$ or $100 \mu \mathrm{M}$ telmisartan for 0,24 and $48 \mathrm{~h}$. Cell viability was assessed using CCK- 8 assays ( ${ }^{* *} \mathrm{P}<0.01$, compared with the untreated group).

Arrays were used to determine the levels of p-RTKs and the expression of angiogenesis-related proteins according to previously published procedures (16). Detailed information is provided in Data S1.

Analysis of miRNA arrays. The analysis of miRNA expression is described in Data S1.

Xenograft model analysis. All mice were treated in accordance with the guidelines of the Kagawa University Committee on Experimental Animals. The Kagawa University Animal Care Committee approved the protocol for animal experiments (Registration no. A155). Male BALB/c-nu/ nu mice, 6 weeks of age and average weight of $18.6 \mathrm{~g}(\mathrm{n}=13)$ were obtained from Japan SLC (Shizuoka, Japan). The mice had continuous free access to sterilized ( $\gamma$-irradiated) food (CL-2; CLEA Japan, Inc.) and autoclaved water. In addition, we placed the mice in an environment that reduced stress as much as possible, such as a temperature of $24^{\circ} \mathrm{C}$ a humidity of approximately $36 \%$, and turning off the lights at night. Each mouse was subcutaneously injected in the left flank with $3 \times 10^{6}$ MKN74 cells. After approximately 2 weeks, or when tumors reached a maximum diameter $>3 \mathrm{~mm}, 13$ mice were randomly assigned to the 
A

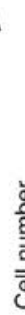

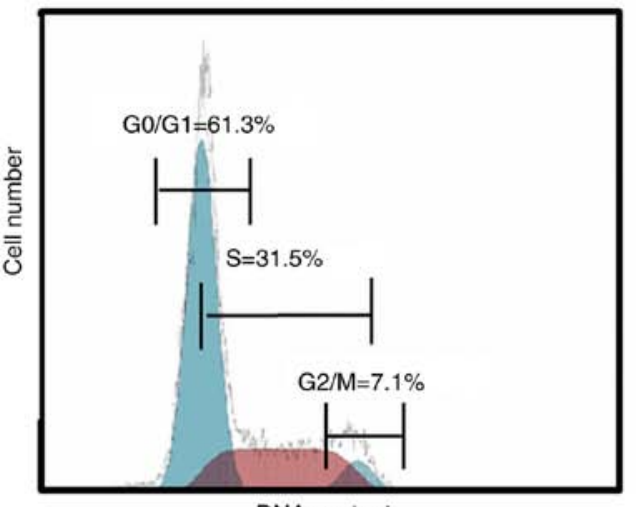

DNA content

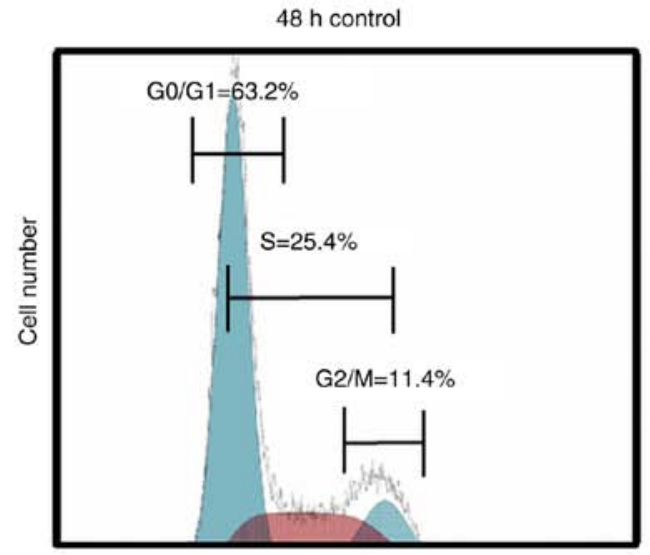

DNA content

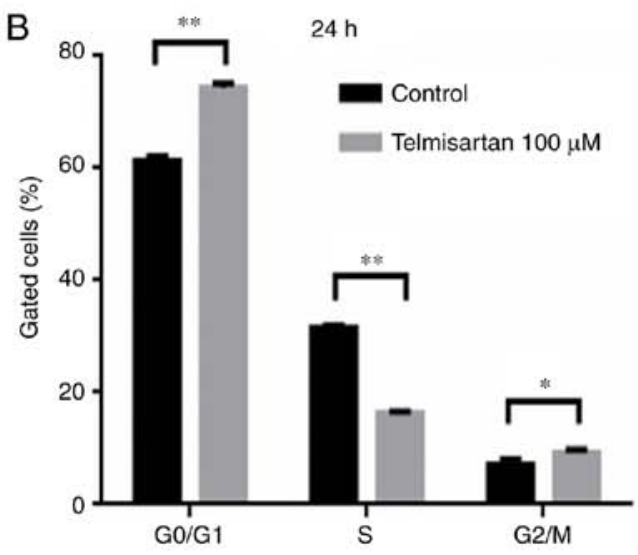

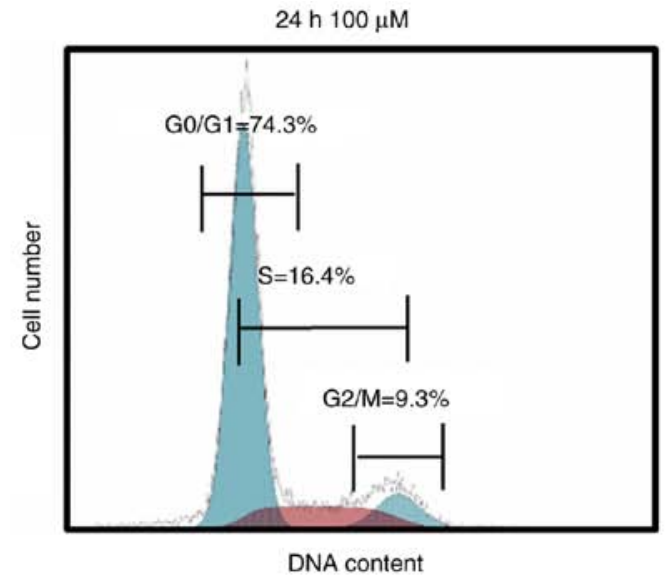

$48 \mathrm{~h} 100 \mu \mathrm{M}$

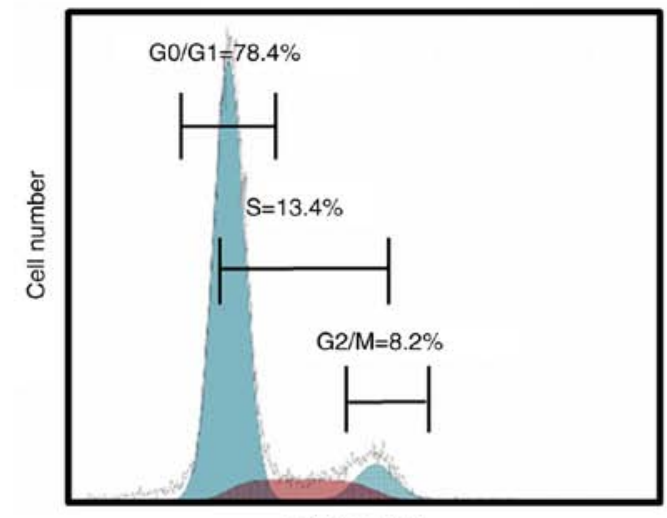

DNA content

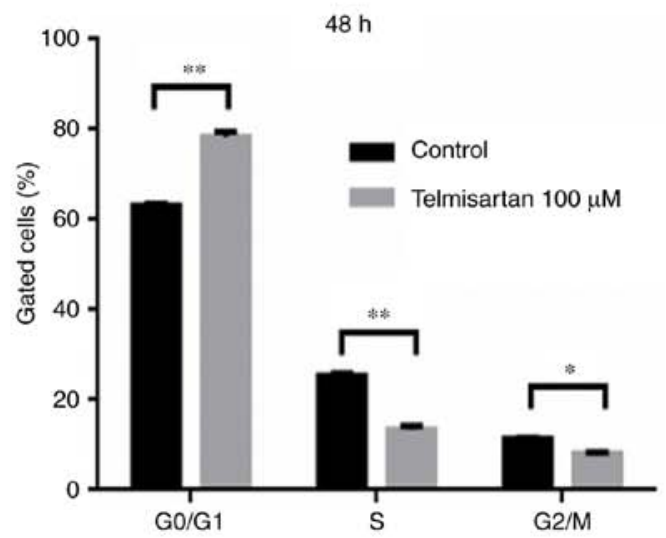

Figure 2. Telmisartan induces the arrest of the cell cycle in MKN74 cells at the G0/G1 phase. (A) Representative results showing the distributions of MKN74 cells in G0/G1, S, and G2/M phases after treatment with 0 or $100 \mu \mathrm{M}$ telmisartan after 24 and $48 \mathrm{~h}$. (B) Percentages of MKN74 cells in G0/G1, S, and $\mathrm{G} 2 / \mathrm{M}$ phases, respectively $\left({ }^{* *} \mathrm{P}<0.01,{ }^{*} \mathrm{P}<0.05\right.$, compared with the control group).

groups as follows: DMSO only (control) $(\mathrm{n}=7)$ and intraperitoneally (i.p.) injected with telmisartan (50 mg/day, $\mathrm{n}=6)$. We also used inhalational anesthesia with $1 \%$ sevoflurane prior to drug administration. The main measurements were body weight and tumor volume, which were recorded every 3 days. We used a total of 13 mice for this experiment and all were euthanized at the end of the experiment. We used carbon dioxide inhalation as a method of euthanasia. The experiment period was 12 days. No mice died during the experiment. We decided to euthanize mice if the tumor volume exceeded $2000\left(\mathrm{~mm}^{3}\right)$. In addition, it was also applied when a low body weight of more than $20 \%$ was observed as compared with the control group. Moreover, when we observed behavioral disorders such as feeding, difficulty in water intake, and continuous lying down in mice, and when we noticed a poor physical condition visually, we decided to perform euthanasia as a humane endpoint. Tumor volumes were calculated as follows: Volume=length $\mathrm{x}$ width ${ }^{2} / 2$ as previously reported $(16,19)$.

Statistical analyses. Results are expressed at the mean \pm SD (standard deviation). Statistical analyses were performed using GraphPad Prism 6 software (GraphPad Software, Inc.). Comparisons among the different groups ( $>2$ groups) were analyzed by one-way ANOVA and Tukey's post hoc test, while 
Student's t-test was used for comparisons between 2 groups. $\mathrm{P}<0.05$ was considered to indicate a significant difference.

\section{Results}

Telmisartan suppresses the proliferation of human gastric cancer cells. Human gastric cancer cell lines were treated with different concentrations $(0,25,50$ and $100 \mu \mathrm{M})$ of telmisartan for 24 or $48 \mathrm{~h}$. Telmisartan suppressed the proliferation of the gastric cancer cells, which was time- and concentration-dependent (Fig. 1).

Telmisartan suppresses the proliferation of human gastric cancer cells by inducing cell cycle arrest at the G0/G1 phase. We used flow cytometry to further investigate the effects of telmisartan on the cell cycle of gastric cancer cells. When MKN74 cells were incubated with $100 \mu \mathrm{M}$ telmisartan for 24 and $48 \mathrm{~h}$, the numbers of cells in the $\mathrm{S}$ and $\mathrm{G} 0 / \mathrm{G} 1$ phases were significantly decreased and increased, respectively, compared with the control cells (Fig. 2A and B). Furthermore, the levels of cyclin D1, CDK4, and phosphorylated retinoblastoma protein $(\mathrm{pRb})$ were decreased (Fig. 3). These results indicated that telmisartan suppressed the growth of MKN74 cells by impairing the progression of the cell cycle.

Telmisartan does not induce MKN74 cells to undergo apoptosis. We used flow cytometry to investigate how telmisartan influences the growth of MKN74 cells (Fig. 4A). Telmisartan did not significantly alter the proportion of apoptotic cells $24 \mathrm{~h}$ after treatment of MKN74 cells (Fig. 4B). Furthermore, ELISA analysis revealed that the levels of cCK-18 did not significantly increase compared with those of the controls (Fig. 4C). These results indicate that telmisartan suppressed the proliferation of MKN74 cells without inducing apoptosis.

Telmisartan increases the levels of angiogenesis-associated proteins expressed by MKN74 cells. We used an antibody array to detect proteins associated with angiogenesis expressed by MKN74 cells treated with telmisartan (Fig. 5A). The levels of TIMP-1 and Serpin E1 were significantly increased compared with those of the controls (Fig. 5B and C).

Phosphorylation of p-RTKs in MKN74 cells treated with telmisartan. We analyzed an array comprising $49 \mathrm{p}$-RTKs to identify RTKs involved in the antiproliferative effect of treating MKN74 cells for $48 \mathrm{~h}$ with $100 \mu \mathrm{M}$ telmisartan (Fig. 6A). Among the p-RTKs analyzed, the level of phosphorylated epidermal growth factor receptor (p-EGFR) was significantly decreased to $44.1 \%$ of that of the untreated cells (Fig. 6B and C).

Telmisartan suppresses tumor growth in vivo. We employed a mouse xenograft model of gastric cancer to test the potential anticancer effects of telmisartan. The volumes of tumors induced by MKN74 cells were $19.6 \%$ lower compared with those of the controls without affecting the weight of the mice (Fig. 7A and B), and there was no difference in pain-associated behaviors of the telmisartan-treated and control mice.

Effect of telmisartan on miRNA expression. We examined the expression levels of 2,555 miRNAs in MKN74 cells cultured

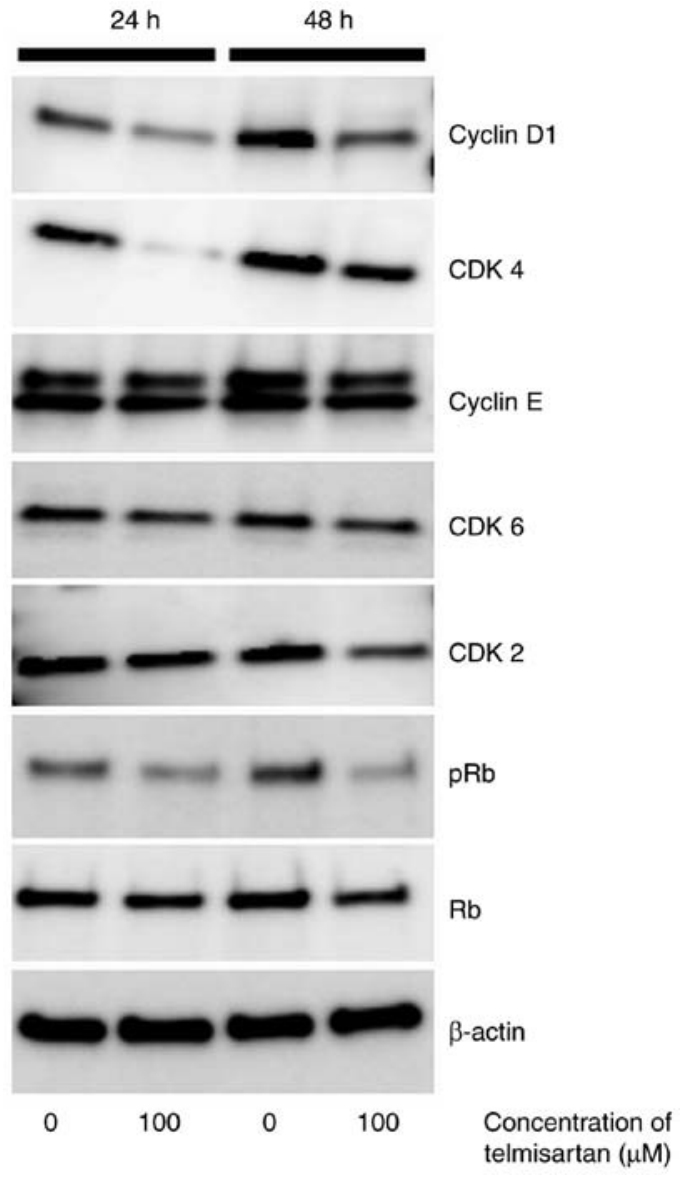

Figure 3. Western blot analysis of the expression of cyclin D1, cyclin E, $\mathrm{CDK} 4$, and phosphorylated $\mathrm{Rb}(\mathrm{pRb})$ in MKN74 cells treated with $100 \mu \mathrm{M}$ telmisartan for 24 and $48 \mathrm{~h}$. The levels of cyclin D1 and its catalytic subunit CDK4 were decreased by $100 \mu \mathrm{M}$ telmisartan compared with those of the control. The phosphorylation of $\mathrm{Rb}(\mathrm{pRB})$ decreased to the same level as $\mathrm{Rb}$. These data suggest that $100 \mu \mathrm{M}$ telmisartan contributes to the arrest of cells in the G1 phase. CDK4, cyclin dependent kinase 4.

with or without $100 \mu \mathrm{M}$ telmisartan. After normalization and deletion of miRNAs with missing values, the hierarchical clustering of 369 miRNAs identified 28 miRNAs that were differentially expressed (Fig. 8). Among these miRNAs, the levels of 16 and 12 were increased and decreased, respectively (Table I).

\section{Discussion}

Environmental factors are strongly related to the cause of gastric cancer (20). Nonsteroidal anti-inflammatory drugs and reproductive hormones decrease the risk of gastric cancer (21-23). Telmisartan and other angiotensin receptor blockers (ARBs) are effective for treating hypertension, chronic heart failure, and chronic kidney disease. ARBs including telmisartan are widely prescribed to treat these pathologies. Moreover, angiotensin II is associated with cancer progression, and ARBs suppress tumor growth by antagonizing the AT1 receptor (10-12,24). In contrast, telmisartan inhibits different types of cancers; adult T-cell leukemia cells, esophageal adenocarcinoma, hepatocellular carcinoma and cholangiocarcinoma (15-18). Here we evaluated the effect of telmisartan on human gastric cancer cell lines and found that 

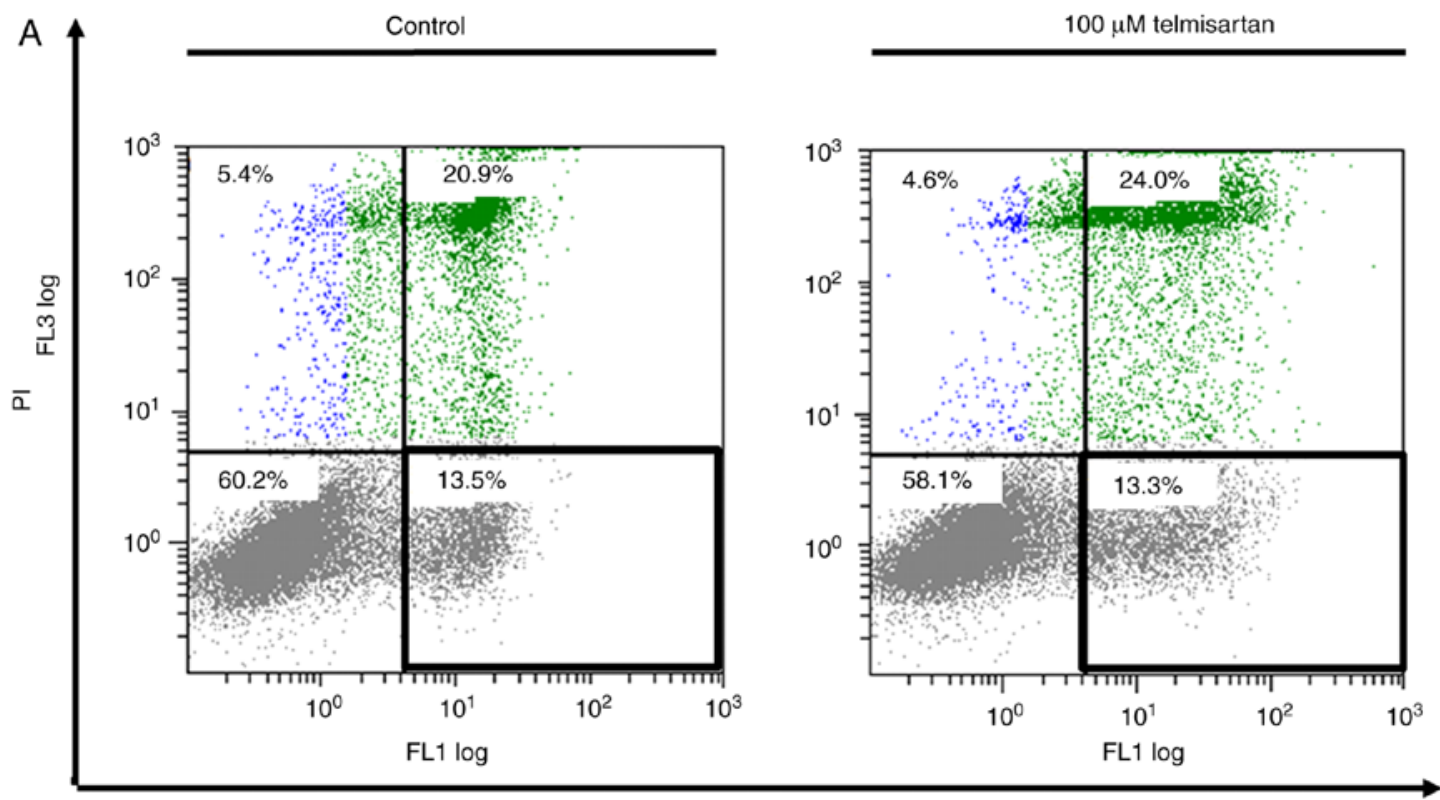

Annexin-V
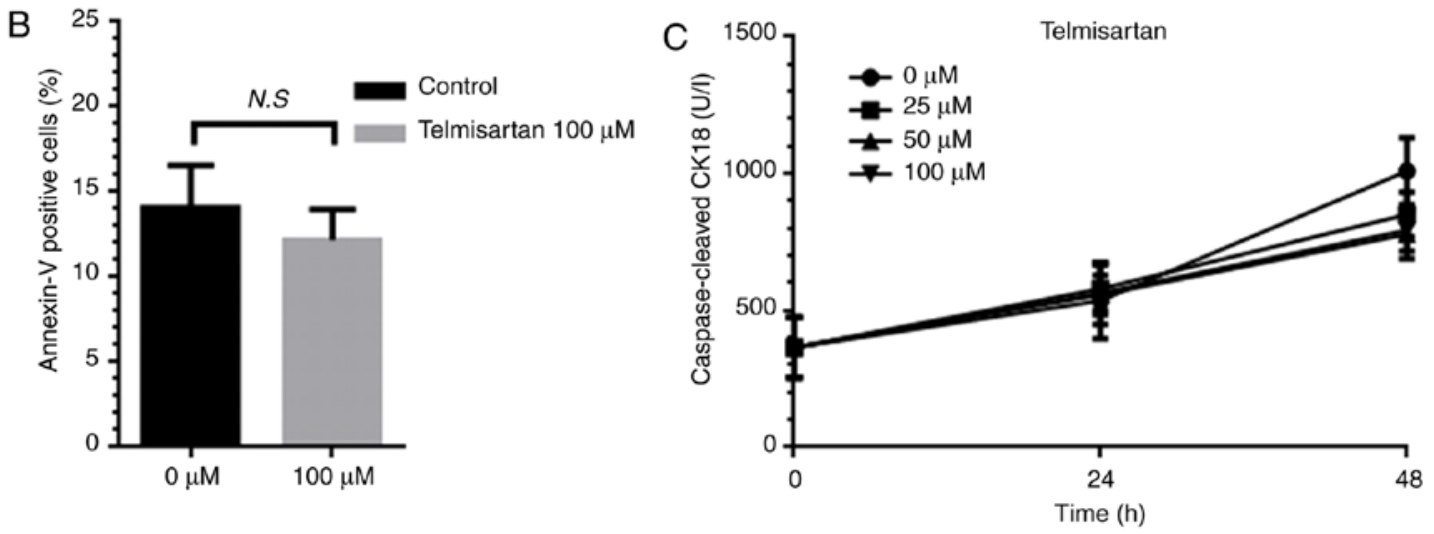

Figure 4. Telmisartan does not induce MKN74 cells to undergo apoptosis. Apoptosis was assessed using flow cytometry $24 \mathrm{~h}$ after MKN74 cells were treated with $100 \mu \mathrm{M}$ telmisartan. (A) Representative data. The gated area corresponding to Annexin V-positive cells is enclosed by the box. (B) There was no significant difference in the number of Annexin V-positive cells between the control- and telmisartan-treated cultures (N.S, not significant). (C) Caspase-cleaved keratin 18 (cCK18) was measured using an ELISA. There was no detectable increase in the level of cCK18 in MKN74 cells treated with $100 \mu \mathrm{M}$ telmisartan, suggesting that apoptosis was not induced.

telmisartan suppressed the proliferation of MKN74, MKN1 and MKN45 cells, indicating the potential of telmisartan to serve as an anticancer drug. Moreover, the antiproliferative effects of telmisartan were associated with cell cycle arrest. In particular, of the three gastric cancer cell lines, MKN74 cells were the least sensitive to telmisartan-mediated cell death. Therefore, we chose MKN74 cells as a model for further studies.

Dysregulation of the cell cycle and consequent robust proliferation are hallmarks of cancer cells (25). Cyclins regulate the cell cycle, and cell proliferation is controlled by complexes formed by cyclin and cyclin-dependent kinases (CDKs) $(26,27)$. For example, the cyclin D1-CDK4/6 complex is required for progression through G1 phase. Here we showed that telmisartan induced G0/G1-phase arrest of a gastric cancer cell line by decreasing the levels of cyclin D1, CDK4, as well as the phosphorylation of the tumor suppressor retinoblastoma $(\mathrm{pRb})$ protein in the western blotting. Our investigations using a xenograft model of gastric cancer further verify that telmisartan inhibited tumor growth through inhibition of the expression of cyclin D1. Other studies have demonstrated that telmisartan induces cell cycle arrest in the G0/G1 phase by inhibiting the expression of cyclin D1 (15-18). In contrast, telmisartan was found to induce cell cycle arrest at the $\mathrm{S}$ phase by inhibiting the expression of cyclin A2 and CDK2 in esophageal squamous cell carcinoma (28). This discrepancy may reflect differences in tumor differentiation, cell phenotypes, and the characteristics of in vitro models.

Telmisartan was previously found to suppress cell proliferation by inducing apoptosis of cancer cell lines, including those derived from cancers of the prostate (29), kidney (30), endometrium (14), and colon (31). Here we were unable to detect apoptosis of MKN74 cells treated with telmisartan. We conclude therefore that the induction of apoptosis is not associated with the suppression of proliferation. These findings suggest that telmisartan mainly suppresses the proliferation of gastric cancer cells by arresting the cell cycle and not by inducing apoptosis. 


\begin{tabular}{|c|c|c|c|c|c|c|c|c|c|c|c|}
\hline $\begin{array}{l}\text { Reference } \\
\text { spots }\end{array}$ & & Activin A & ADAMTS-1 & Angiogenin & $\begin{array}{c}\text { Angio } \\
\text { poietin-1 }\end{array}$ & $\begin{array}{c}\text { Angio } \\
\text { poietin-2 }\end{array}$ & $\begin{array}{c}\text { Angiostatin/ } \\
\text { plasminogen }\end{array}$ & $\begin{array}{l}\text { Amphi } \\
\text { regulin }\end{array}$ & Artemin & & $\begin{array}{c}\text { Reference } \\
\text { spots }\end{array}$ \\
\hline $\begin{array}{c}\text { Coagulation } \\
\text { factor } 3\end{array}$ & CXCL16 & DPP 4 & EGF & EG-VEGF & Endoglin & $\begin{array}{l}\text { Endostatin/ } \\
\text { collagen18 }\end{array}$ & Endothelin -1 & FGF acidic & FGF basic & FGF-4 & FGF-7 \\
\hline GDNF & GM-CSF & HB-EGF & HGF & IGFBP-1 & IGFBP-2 & IGFBP-3 & IL-1 $\beta$ & IL-8 & $\begin{array}{c}\text { LAP } \\
\text { (TGF-p1) }\end{array}$ & Leptin & MCP-1 \\
\hline MIP-1 $1 \alpha$ & MMP-8 & MMP-9 & NRG1- $\beta 1$ & $\mid \begin{array}{c}\text { Pentraxin } 3 \\
\text { (PTX3) }\end{array}$ & PD-ECGF & PDGF-AA & \begin{tabular}{|c|} 
PDEF- \\
AB/PDGF- \\
BB \\
\end{tabular} & Persephin & $\begin{array}{l}\text { Platelet } \\
\text { Factor } 4 \\
\text { (PF4) }\end{array}$ & PIGF & Prolactin \\
\hline Serpin B5 & Serpin E1 & Serpin F1 & TIMP-1 & TIMP-4 & $\begin{array}{l}\text { Thrombo } \\
\text { spondin-1 }\end{array}$ & $\begin{array}{l}\text { Thrombo } \\
\text { spondin-2 }\end{array}$ & UPA & Vasohibin & VEGF & VEGF-C & \\
\hline $\begin{array}{l}\text { Reference } \\
\text { spots }\end{array}$ & & & & & & & & & & & $\begin{array}{l}\text { Negative } \\
\text { control }\end{array}$ \\
\hline
\end{tabular}
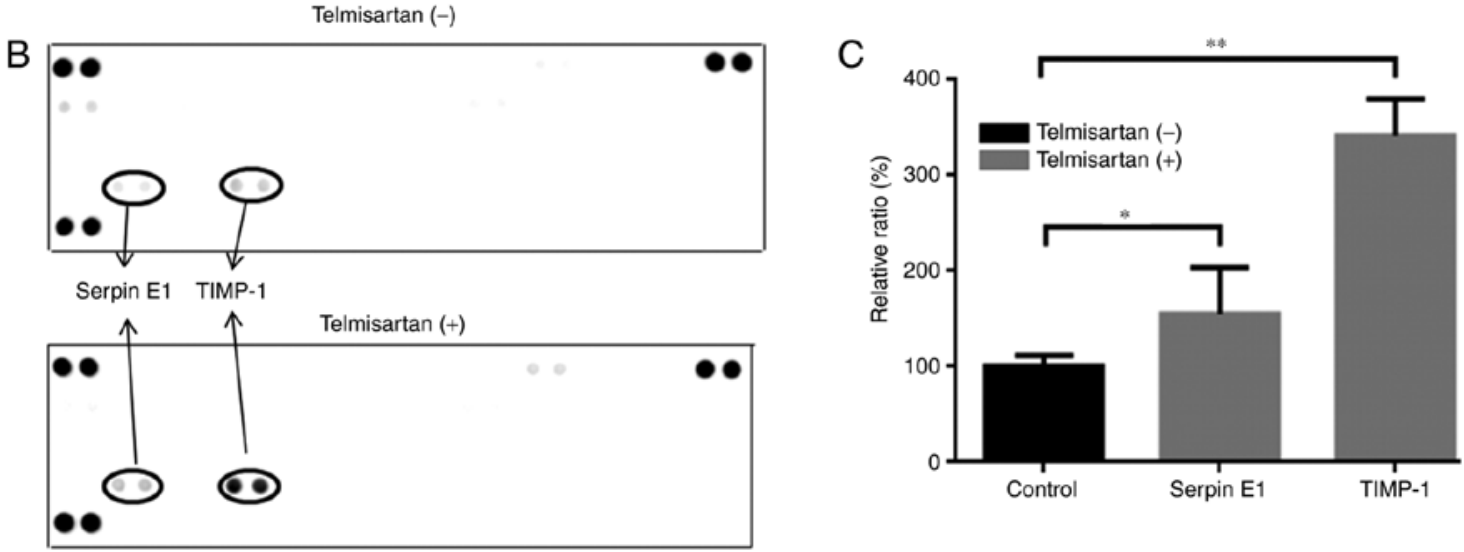

Figure 5. Effects of telmisartan on the production of angiogenesis-associated proteins by MKN74 cells. (A) Array of 55 angiogenesis-associated cytokines. (B) The human-specific angiogenesis antibody array was incubated with extracts of MKN74 cells cultured in the presence or absence of telmisartan. MKN74 cells treated with telmisartan expressed increased levels of TIMP-1 and Serpin E1 compared with the controls. (C) Relative levels of TIMP-1 and Serpin E1 in telmisartan-treated vs. untreated MKN74 cells ( $\mathrm{P}<0.05,{ }^{* *} \mathrm{P}<0.01$, compared with the control group). TIMP-1, tissue inhibitor of metalloproteinase-1; Serpin E1, Serpin family E member 1.

\begin{tabular}{|c|c|c|c|c|c|c|c|c|c|c|c|}
\hline $\begin{array}{c}\text { Reference } \\
\text { spots }\end{array}$ & & & & & & & & & & & $\begin{array}{c}\text { Reference } \\
\text { spots }\end{array}$ \\
\hline EGFR & ErbB2 & ErbB3 & ErbB4 & FGFR1 & FGFR2 $\alpha$ & FGFR3 & FGFR4 & Insulin R & IGF-1R & Axl & Dtk \\
\hline Mer & HGFR & MSPR & PDGFR $\alpha$ & PDGFR & SCFR & Flt-3 & M-CSFR & C-Ret & ROR1 & ROR2 & Tie1 \\
\hline Tie-2 & TrkA & TrkB & TrkC & $\begin{array}{c}\text { VEGF } \\
\text { R1 }\end{array}$ & $\begin{array}{c}\text { VEGF } \\
\text { R2 }\end{array}$ & $\begin{array}{c}\text { VEGF } \\
\text { R3 }\end{array}$ & MuSK & EphA1 & EphA2 & EphA3 & EphA4 \\
\hline EphA6 & EphA7 & EphB1 & EphB2 & EphB4 & EphB6 & ALK & DDR1 & DDR2 & EphA5 & EphA10 & \\
\hline $\begin{array}{c}\text { Reference } \\
\text { spots }\end{array}$ & & EphB3 & PYK & & & & & & & & PBS \\
\hline
\end{tabular}

B

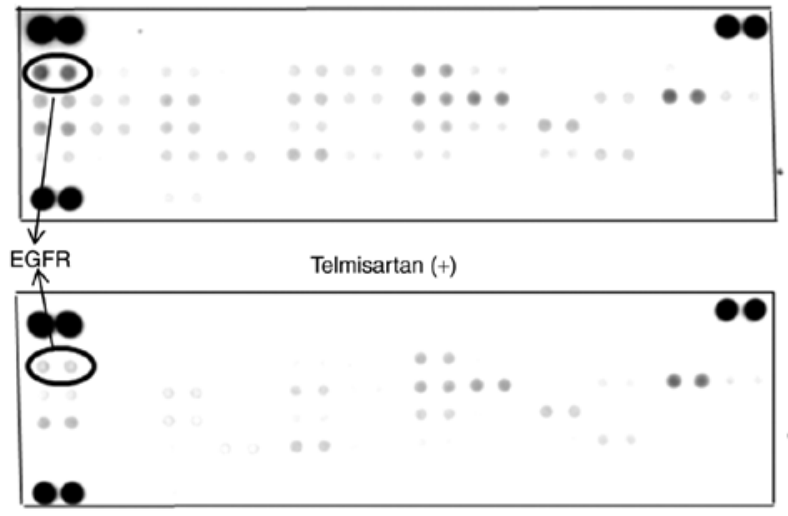

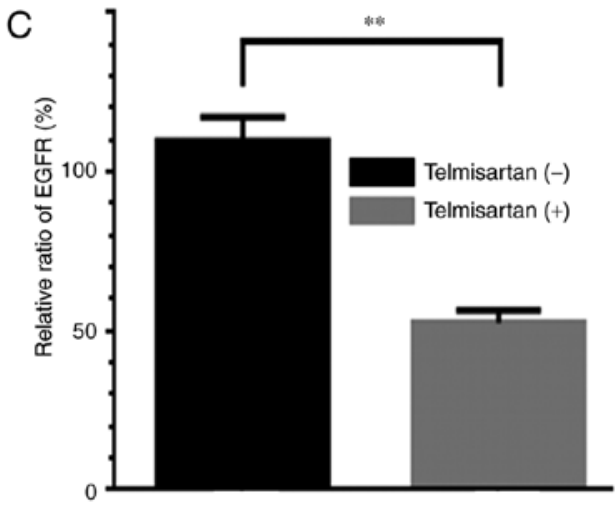

Figure 6. Analysis of RTK phosphorylation in MKN74 cells. (A) p-RTK array of 49 anti-tyrosine kinase antibodies. (B) p-RTK arrays incubated with extracts prepared from MKN74 cells cultured in the presence or absence of telmisartan. Phosphorylation of EGFR in telmisartan-treated cells was lower compared with the controls. (C) Relative levels of p-EGFR in telmisartan-treated vs. untreated MKN74 cells ( ${ }^{* *} \mathrm{P}<0.01$, compared with the control group). p-RTK, phosphorylated receptor tyrosine kinase; EGFR, epidermal growth factor receptor. 

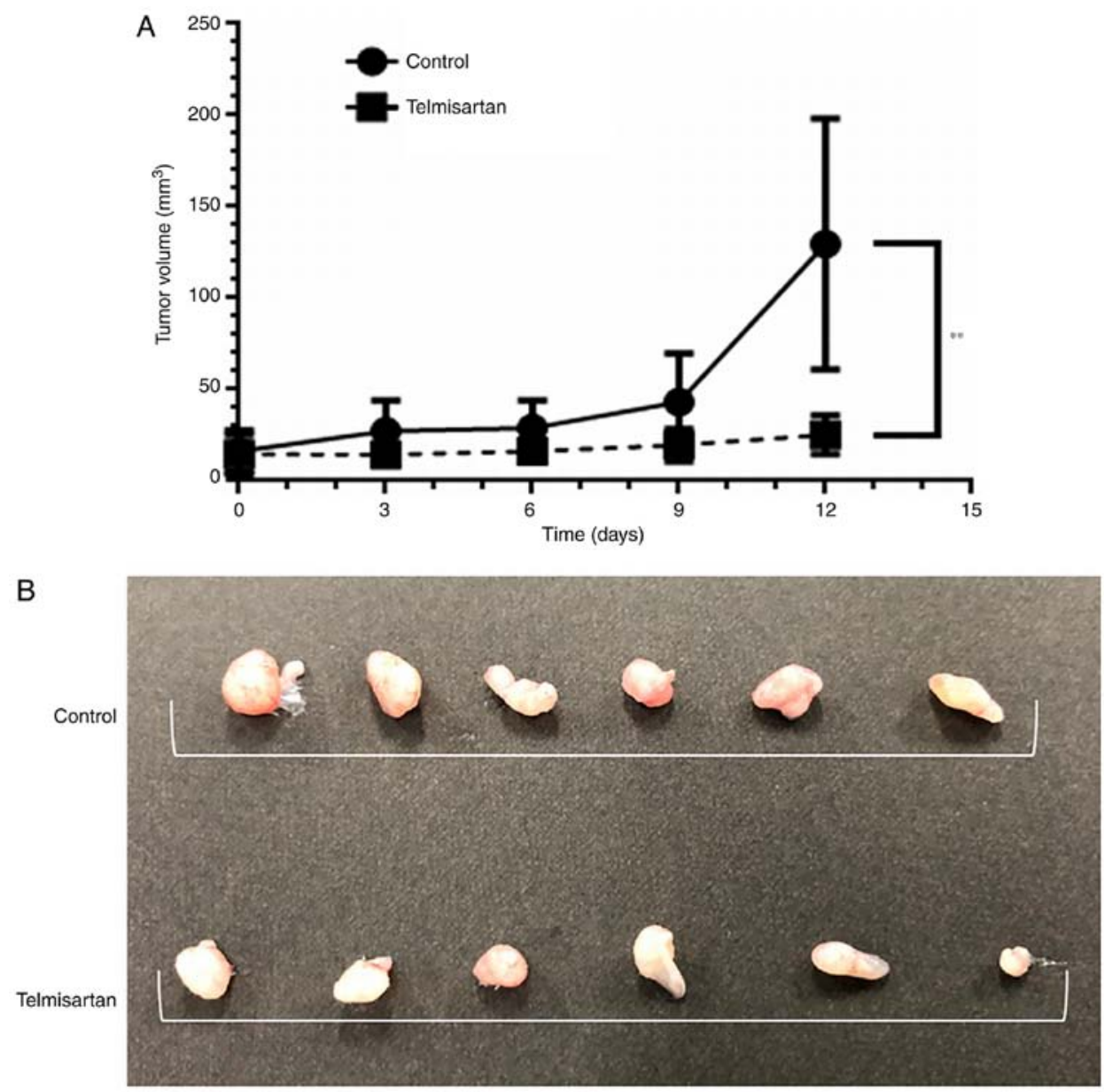

Figure 7. Telmisartan inhibits the proliferation of tumors in a mouse xenograft model of gastric cancer. (A) Tumor growth in mice treated with or without telmisartan. Twelve days after xenografting, the tumor volumes of tumors in mice treated with telmisartan were significantly smaller compared with those of the controls $\left({ }^{* * *} \mathrm{P}<0.01\right)$. (B) Images indicating the tumor sizes of the telmisartan-treated and control mice.

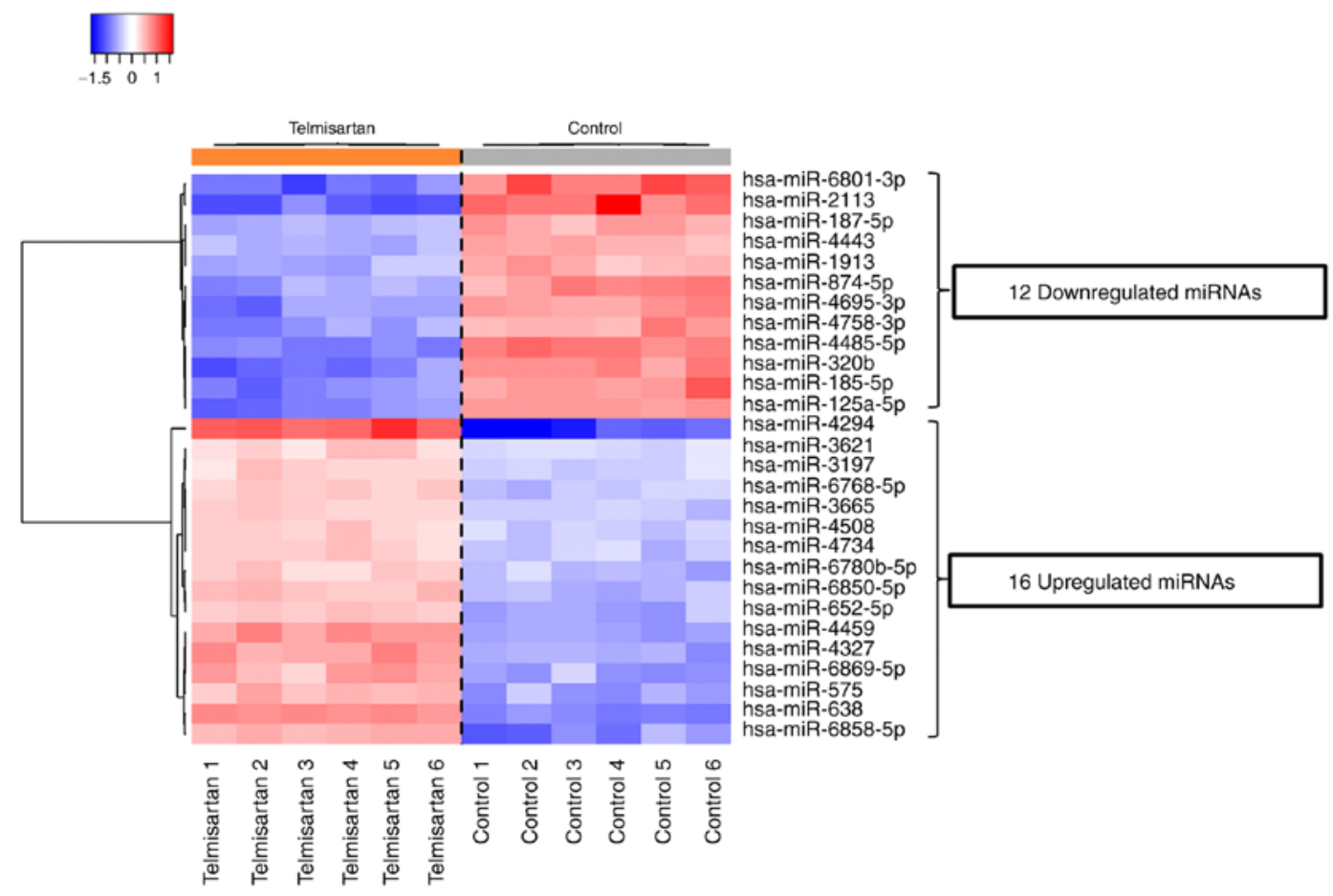

Figure 8. Hierarchical clustering of miRNAs expressed by MKN74 cells treated with or without telmisartan. Samples are in columns and miRNAs are in rows. miRNA clustering is shown using a color scale. Telmisartan-treated MKN74 cells expressed 12 and 16 miRNAs at lower (blue) or higher (red) levels, respectively, compared with the controls. 
Table I. Differential expression of miRNAs in MKN74 cells cultured with or without telmisartan.

\begin{tabular}{|c|c|c|c|}
\hline miRNA & P-value & $\mathrm{FC}$ & Chromosomal localization \\
\hline \multicolumn{4}{|l|}{ Increased } \\
\hline hsa-miR-4294 & $2.18 \mathrm{E}-08$ & 5.01896 & $10 \mathrm{q} 11.23$ \\
\hline hsa-miR-638 & $7.58 \mathrm{E}-13$ & 2.970468 & 19p13.2 \\
\hline hsa-miR-6858-5p & 7.78E-08 & 2.595125 & Xq28 \\
\hline hsa-miR-4459 & $1.01 \mathrm{E}-10$ & 2.507542 & $5 q 11.2$ \\
\hline hsa-miR-4327 & 4.65E-09 & 2.410159 & $21 q 22.11$ \\
\hline hsa-miR-6869-5p & $8.69 \mathrm{E}-08$ & 2.373717 & $20 \mathrm{p} 13$ \\
\hline hsa-miR-575 & $1.29 \mathrm{E}-08$ & 2.240823 & 4 \\
\hline hsa-miR-652-5p & $1.12 \mathrm{E}-08$ & 2.040954 & $\mathrm{X}$ \\
\hline hsa-miR-6850-5p & $1.85 \mathrm{E}-09$ & 1.964441 & $8 \mathrm{q} 24.3$ \\
\hline hsa-miR-6780b-5p & 7.1E-08 & 1.842044 & $6 \mathrm{p} 21.1$ \\
\hline hsa-miR-6768-5p & $1.41 \mathrm{E}-08$ & 1.756206 & $16 \mathrm{p} 13.3$ \\
\hline hsa-miR-4734 & $3.67 \mathrm{E}-08$ & 1.713983 & $17 \mathrm{q} 12$ \\
\hline hsa-miR-3665 & $4.44 \mathrm{E}-10$ & 1.69717 & $13 q 22.3$ \\
\hline hsa-miR-4508 & $1.47 \mathrm{E}-08$ & 1.682616 & $15 \mathrm{q} 11.2$ \\
\hline hsa-miR-3197 & $8.06 \mathrm{E}-09$ & 1.637298 & $21 \mathrm{q} 22.2$ \\
\hline hsa-miR-3621 & 8.39E-08 & 1.576307 & $9 q 34.3$ \\
\hline \multicolumn{4}{|l|}{ Decreased } \\
\hline hsa-miR-2113 & $6.97 \mathrm{E}-08$ & 0.234941 & $6 q 16.1$ \\
\hline hsa-miR-6801-3p & $1.03 \mathrm{E}-08$ & 0.264563 & $19 \mathrm{q} 13.41$ \\
\hline hsa-miR-4485-5p & $2.32 \mathrm{E}-12$ & 0.309017 & $11 \mathrm{p} 15.4$ \\
\hline hsa-miR-320b & 3.23E-09 & 0.314524 & 1 \\
\hline hsa-miR-185-5p & 2.3E-08 & 0.345032 & $22 q 11.21$ \\
\hline hsa-miR-125a-5p & $3.6 \mathrm{E}-10$ & 0.346496 & $19 q 13.41$ \\
\hline hsa-miR-4695-3p & $2.34 \mathrm{E}-08$ & 0.376426 & $1 \mathrm{p} 36.13$ \\
\hline hsa-miR-874-5p & $1.92 \mathrm{E}-08$ & 0.381128 & $5 \mathrm{q} 31.2$ \\
\hline hsa-miR-4758-3p & $6.51 \mathrm{E}-08$ & 0.402079 & $20 q 13.33$ \\
\hline hsa-miR-187-5p & $1.46 \mathrm{E}-09$ & 0.442281 & $18 \mathrm{q} 12.2$ \\
\hline hsa-miR-1913 & 4.44E-08 & 0.459243 & 6q27 \\
\hline hsa-miR-4443 & $6.92 \mathrm{E}-10$ & 0.469228 & $3 \mathrm{p} 21.31$ \\
\hline
\end{tabular}

Fold-changes (FCs) are expressed as the level in telmisartan-treated/untreated cells. Fold-changes (FCs) $>1.5$, Fold-changes $(\mathrm{FCs})<0.67$, $\mathrm{P}<1 \times 10^{7}$. Fold-changes (FCs) are the comparison of the signal values of the treatment group and the control group.

The ARB candesartan was previously found to significantly inhibit the expression of transforming growth factor b1 (TGF-b1) to suppress tumor growth as well as stromal fibrosis (19). Furthermore, candesartan significantly suppressed the growth of tumor xenografts and angiogenesis in mice (19). Here we showed that MKN74 cells treated with telmisartan expressed elevated levels of the anti-angiogenesis factor TIMP-1. Overexpression of tissue inhibitor of metalloproteinase-1 (TIMP-1) shortens disease-free and overall survival of patients with gastric cancer $(32,33)$. Therefore, overexpression of TIMP-1 by gastric cancer cells may be associated with poor prognosis, indicating the transition to a more aggressive malignant phenotype.

Our results are not consistent with the antiproliferative effects of telmisartan on gastric cancer cells published by others $(32,33)$. Our present results are consistent with the presence of a subpopulation of telmisartan-resistant cells in cultures of the MKN74 cell line. These results suggest that telmisartan may be used in combination with conventional anticancer drugs or other molecularly-targeted therapeutics, particularly those that inhibit angiogenesis. Evidence indicates that overexpression of serpin E1, which is similar to TIMP-1, is a marker of poor prognosis (34) as is TIMP-1.

Members of the epidermal growth factor receptor (EGFR) family activate intracellular signaling pathways in response to extracellular signals (35). Further, EGFR activation contributes to cell cycle progression, as it is associated with the expression of cyclin D1 (25). Thus, telmisartan may regulate the growth of MKN74 cells by inhibiting the activation of EGFR, which is reflected by its phosphorylation on specific tyrosine residues. Furthermore, we previously found that telmisartan inhibits the growth of cancer cells through the regulation of EGFR $(16,18)$. For example, EGFR is preferentially activated in gastric cancer vs. normal tissues (36). Here we found that telmisartan inhibited the phosphorylation of EGFR in MKN74 cells. We further showed in the present study that the phosphorylation 
of EGFR was suppressed after $24 \mathrm{~h}$ but not at $48 \mathrm{~h}$ after cells were treated with telmisartan (data not shown). Therefore, these data suggest that early after its addition to cultures of gastric cancer cells, telmisartan inhibited the phosphorylation of EGFR.

Telmisartan affects the miRNA expression profile of cancer cells (16-18). Here we identified 28 differentially expressed miRNAs in MKN74 cells treated with telmisartan when compared to controls. miR-185-5p, which was found to be expressed at lower levels, is a reliable diagnostic biomarker of gastric cancer (37). In contrast, miR-187, which was expressed at lower levels in MKN74 cells and is overexpressed in gastric cancer tissues, is associated with factors that influence the malignant phenotype (38).

Overexpression of miR-187 was previously found to promote the proliferation, migration, and invasion of gastric cancer cells by targeting tumor suppressor CRMP1 (38). Thus, telmisartan may exert its antitumor effects by inhibiting the expression of miRNAs. The relationship between cell cycle arrest and these two miRNAs is unknown and requires further study.

In conclusion, in the present study, it was demonstrated that telmisartan inhibited the proliferation of a human gastric cancer cell line in vivo and in vitro through cell cycle arrest. Moreover, we provide compelling evidence that the inactivation of the EGFR and the changes in the levels of an angiogenesis-associated protein and those of two miRNAs contributed to the antitumor effects of telmisartan.

\section{Acknowledgements}

The authors thank Kayo Hirose, Miwako Watanabe, Keiko Fujikawa, Megumi Okamura, Mari Yamada and Fuyuko Kokado from the Department of Gastroenterology and Neurology, Kagawa University for their assistance with the experiments.

\section{Funding}

No funding was received.

\section{Availability of data and materials}

The datasets used or analyzed during the present study are available from the corresponding author on reasonable request. Supplementary information is included in Data S1.

\section{Author's contributions}

NF and TM designed the experiments. KF, HI, HKo, TC, DN, HY, TK, KT, MH, KKo, KKa, HKa, AM, KT, TH, KO and YS conducted the experiments, analyzed data, and wrote the manuscript. SF and TM were involved in research design and contributed to writing the manuscript. All authors read and approved the final version of the manuscript.

\section{Ethics approval and consent to participate}

All mice were treated in accordance with the guidelines of the Kagawa University Committee on Experimental Animals. The Kagawa University Animal Care Committee approved the protocol for animal experiments (Registration no. A155).

\section{Patient consent for publication}

Not applicable.

\section{Competing interests}

The authors declare that they have no competing interests.

\section{References}

1. Jemal A, Bray F, Center MM, Ferlay J, Ward E and Forman D: Global cancer statistics. CA Cancer J Clin 61: 69-90, 2011.

2. Correa P: Gastric cancer: Two epidemics? Dig Dis Sci 56: 1585-1586, author reply 1586, 2011.

3. Salvon-Harman JC, Cady B, Nikulasson S, Khettry U, Stone MD and Lavin P: Shifting proportions of gastric adenocarcinomas. Arch Surg 129: 381-388, discussion 388-389, 1994.

4. Bilici A: Treatment options in patients with metastatic gastric cancer: Current status and future perspectives. World J Gastroenterol 20: 3905-3915, 2014.

5. Akama Y, Yasui W, Yokozaki H, Kuniyasu H, Kitahara K, Ishikawa T and Tahara E: Frequent amplification of the cyclin $\mathrm{E}$ gene in human gastric carcinomas. Jpn J Cancer Res 86: 617-621, 1995.

6. Bani-Hani KE, Almasri NM, Khader YS, Sheyab FM and Karam HN: Combined evaluation of expressions of cyclin $\mathrm{E}$ and $\mathrm{p} 53$ proteins as prognostic factors for patients with gastric cancer. Clin Cancer Res 11: 1447-1453, 2005.

7. Sun Y, Li JY, He JS, Zhou LX and Chen K: Tissue microarray analysis of multiple gene expression in intestinal metaplasia, dysplasia and carcinoma of the stomach. Histopathology 46: 505-514, 2005.

8. Takano Y, Kato Y, van Diest PJ, Masuda M, Mitomi H and Okayasu I: Cyclin D2 overexpression and lack of p27 correlate positively and cyclin E inversely with a poor prognosis in gastric cancer cases. Am J Pathol 156: 585-594, 2000.

9. Shan YS, Hsu HP, Lai MD, Hung YH, Wang CY, Yen MC and Chen YL: Cyclin D1 overexpression correlates with poor tumor differentiation and prognosis in gastric cancer. Oncol Lett 14: 4517-4526, 2017.

10. Okamoto K, Tajima H, Ohta T, Nakanuma S, Hayashi H, Nakagawara H, Onishi I, Takamura H, Ninomiya I, Kitagawa $\mathrm{H}$, et al: Angiotensin II induces tumor progression and fibrosis in intrahepatic cholangiocarcinoma through an interaction with hepatic stellate cells. Int J Oncol 37: 1251-1259, 2010.

11. Du N, Feng J, Hu LJ, Sun X, Sun HB, Zhao Y, Yang YP and Ren H: Angiotensin II receptor type 1 blockers suppress the cell proliferation effects of angiotensin II in breast cancer cells by inhibiting AT1R signaling. Oncol Rep 27: 1893-1903, 2012.

12. Kinoshita J, Fushida S, Harada S, Yagi Y, Fujita H, Kinami S, Ninomiya I, Fujimura T, Kayahara M, Yashiro M, et al: Local angiotensin II-generation in human gastric cancer: Correlation with tumor progression through the activation of ERK1/2, NF-kappaB and survivin. Int J Oncol 34: 1573-1582, 2009.

13. Matsuyama M, Funao K, Kuratsukuri K, Tanaka T, Kawahito Y, Sano H, Chargui J, Touraine JL, Yoshimura N and Yoshimura R: Telmisartan inhibits human urological cancer cell growth through early apoptosis. Exp Ther Med 1: 301-306, 2010.

14. Koyama N, Nishida Y, Ishii T, Yoshida T, Furukawa $Y$ and Narahara H: Telmisartan induces growth inhibition, DNA double-strand breaks and apoptosis in human endometrial cancer cells. PLoS One 9: e93050, 2014.

15. Kozako T, Soeda S, Yoshimitsu M, Arima N, Kuroki A, Hirata S, Tanaka H, Imakyure O, Tone N, Honda S and Soeda S: Angiotensin II type 1 receptor blocker telmisartan induces apoptosis and autophagy in adult T-cell leukemia cells. FEBS Open Bio 6: 442-460, 2016.

16. Fujihara S, Morishita A, Ogawa K, Tadokoro T, Chiyo T, Kato K, Kobara H, Mori H, Iwama $\mathrm{H}$ and Masaki T: The angiotensin II type 1 receptor antagonist telmisartan inhibits cell proliferation and tumor growth of esophageal adenocarcinoma via the AMPK $\alpha / m$ TOR pathway in vitro and in vivo. Oncotarget 8 : 8536-8549, 2017

17. Oura K, Tadokoro T, Fujihara S, Morishita A, Chiyo T, Samukawa E, Yamana Y, Fujita K, Sakamoto T, Nomura T, et al: Telmisartan inhibits hepatocellular carcinoma cell proliferation in vitro by inducing cell cycle arrest. Oncol Rep 38: 2825-2835, 2017. 
18. Samukawa E, Fujihara S, Oura K, Iwama H, Yamana Y, Tadokoro T, Chiyo T, Kobayashi K, Morishita A, Nakahara M, et al: Angiotensin receptor blocker telmisartan inhibits cell proliferation and tumor growth of cholangiocarcinoma through cell cycle arrest. Int J Oncol 51: 1674-1684, 2017.

19. Okazaki M, Fushida S, Harada S, Tsukada T, Kinoshita J, Oyama K, Tajima H, Ninomiya I, Fujimura T and Ohta T: The angiotensin II type 1 receptor blocker candesartan suppresses proliferation and fibrosis in gastric cancer. Cancer Lett 355 46-53, 2014.

20. Karimi P, Islami F, Anandasabapathy S, Freedman ND and Kamanqar F: Gastric cancer: Descriptive epidemiology, risk factors, screening, and prevention. Cancer Epidemiol Biomarkers Prev 5: 700-713, 2014

21. Wu CY, Wu MS, Kuo KN, Wang CB, Chen YJ and Lin JT: Effective reduction of gastric cancer risk with regular use of nonsteroidal anti-inflammatory drugs in Helicobacter pylori-infected patients. J Clin Oncol 28: 2952-2957, 2010.

22. Epplein M, Nomura AM, Wilkens LR, Henderson BE and Kolonel LN: Nonsteroidal antiinflammatory drugs and risk of gastric adenocarcinoma: The multiethnic cohort study. Am J Epidemiol 170: 507-514, 2009.

23. Freedman ND, Chow WH, Gao YT, Shu XO, Ji BT, Yang G, Lubin JH, Li HL, Rothman N, Zheng W and Abnet CC: Menstrual and reproductive factors and gastric cancer risk in a large prospective study of women. Gut 56: 1671-1677, 2007.

24. D'Incalci M, Colombo T, Ubezio P, Nicoletti I, Giavazzi R, Erba E, Ferrarese L, Meco D, Riccardi R, Sessa C, et al: The combination of yondelis and cisplatin is synergistic against human tumor xenografts. Eur J Cancer 39: 1920-1926, 2003.

25. Kato K, Gong J, Iwama H, Kitanaka A, Tani J, Miyoshi H, Nomura K, Mimura S, Kobayashi M, Aritomo Y, et al: The antidiabetic drug metformin inhibits gastric cancer cell proliferation in vitro and in vivo. Mol Cancer Ther 11: 549-560, 2012.

26. Cordon-Cardo C: Mutations of cell cycle regulators. Biological and clinical implications for human neoplasia. Am J Pathol 147: $545-560,1995$.

27. Hunter T and Pines J: Cyclins and cancer. II: Cyclin D and CDK inhibitors come of age. Cell 79: 573-582, 1994

28. Matsui T, Chiyo T, Kobara H, Fujihara S, Fujita K, Namima D, Nakahara M, Kobayashi N, Nishiyama N, Yachida T, et al: Telmisartan inhibits cell proliferation and tumor growth of esophageal squamous cell carcinoma by inducing s-phase arrest in vitro and in vivo. Int J Mol Sci 20: e3197, 2019.
29. Funao K, Matsuyama M, Kawahito Y, Sano H, Chargui J, Touraine JL, Nakatani $\mathrm{T}$ and Yoshimura R: Telmisartan is a potent target for prevention and treatment in human prostate cancer. Oncol Rep 20: 295-300, 2008.

30. Funao K, Matsuyama M, Kawahito Y, Sano H, Chargui J, Touraine JL, Nakatani T and Yoshimura R: Telmisartan as a peroxisome proliferator-activated receptor- $\gamma$ ligand is a new target in the treatment of human renal cell carcinoma. Mol Med Rep 2: 193-198, 2009

31. Lee LD, Mafura B, Lauscher JC, Seeliger H, Kreis ME and Gröne J: Antiproliferative and apoptotic effects of telmisartan in human colon cancer cells. Oncol Lett 8: 2681-2686, 2014.

32. Mimori K, Mori M, Shiraishi T, Fujie T, Baba K, Haraguchi M, Abe R, Ueo $\mathrm{H}$ and Akiyoshi T: Clinical significance of tissue inhibitor of metalloproteinase expression in gastric carcinoma. Br J Cancer 76: 531-536, 1997.

33. Yoshikawa T, Tsuburaya A, Kobayashi O, Sairenji M and Miyagi Y: Protein levels of tissue inhibitor of metalloproteinase-1 in tumor extracts as a marker for prognosis and recurrence in patients with gastric cancer. Gastric Cancer 9: 106-113, 2006

34. Liao P, Li W, Liu R, Teer JK, Xu B, Zhang W, Li X, Mcleod HL and He Y: Genome-scale analysis identifies SERPINE1 and SPARC as diagnostic and prognostic biomarkers in gastric cancer. OncoTargets Ther 11: 6969-6980, 2018.

35. Hsieh AC and Moasser MM: Targeting HER proteins in cancer therapy and the role of the non-target HER3. Br J Cancer 97: 453-457, 20017, 2007.

36. Masaki T, Hatanaka Y, Nishioka M, Tokuda M, Shiratori Y, Reginfo W and Omata M: Activation of epidermal growth factor receptor kinase in gastric carcinoma: A preliminary study. Am J Gastroenterol 95: 2135-2136, 2000.

37. Huang Z, Zhu D, Wu L, He M, Zhou X, Zhang L, Zhang H, Wang W, Zhu J, Cheng W, et al: Six serum-based miRNAs as potential diagnostic biomarkers for gastric cancer. Cancer Epidemiol Biomarkers Prev 26: 188-196, 2017.

38. Ren L, Li F, Di M, Fu Y, Hui Y, Xiao G, Sun Q, Liu Y, Ren D and Du X: MicroRNA-187 regulates gastric cancer progression by targeting the tumor suppressor CRMP1. Biochem Biophys Res Commun 482: 597-603, 2017. 